\title{
TBX10, a member of the $T b x 1$-subfamily of conserved developmental genes, is located at human Chromosome 11q13 and proximal mouse Chromosome 19
}

\author{
David J. Law, ${ }^{1}$ Nancy Garvey, ${ }^{2}$ Sergei I. Agulnik, ${ }^{2}$ Victor Perlroth, ${ }^{2}$ Olwen M. Hahn, ${ }^{2}$ Rita E. Rhinehart, \\ Thomas C. Gebuhr, ${ }^{1}$ Lee M. Silver ${ }^{2}$ \\ ${ }^{1}$ Human Genome Center and Department of Human Genetics, 1150 West Medical Center Drive, 3514 MSRB I, University of Michigan, \\ Ann Arbor, Michigan 48109-0650, USA \\ ${ }^{2}$ Department of Molecular Biology, Princeton University, Princeton, New Jersey 08544, USA
}

Received: 9 October 1997 / Accepted: 9 January 1998

The T-box developmental gene family was originally described in the mouse (Bollag et al. 1994), and homologs were subsequently identified in a wide variety of metazoans (Agulnik et al. 1995). T-box genes encode transcription factors that are expressed differentially during embryogenesis and/or in tissue-specific fashion throughout adulthood (reviewed in Smith 1997). The importance of T-box genes recently was underscored by the identification of TBX gene mutations in two human developmental diseasesTBX5 in Holt-Oram syndrome (Li et al. 1997; Basson et al. 1997) and TBX3 in ulnar-mammary syndrome (Bamshad et al. 1997).

Here we report the isolation and mapping of a new T-box family member, TBX10/Tbx10, in human and mouse. We isolated the human clone from a lambda Charon 4A lymph node genomic library (ATCC LI014), using reduced stringency hybridization with a mouse Tbxl cDNA probe. This probe is comprised of sequence within the highly conserved T-box region of Tbxl (nt258-nt439 of GenBank entry MMU57327), and, as expected, the isolated clone showed high sequence similarity to the T-box of both mouse Tbx1 and human TBX1 (Chieffo et al. 1997). Human TBX1 resides at Chromosome (Chr) 22q11, syntenic to the map location of mouse Tbxl on Chr 16 (Chieffo et al. 1997). Our localization of human TBX10 to Chr 11q13 (Figs. 1, 2A) and gene sequence analysis (Fig. 3) confirm that the isolated gene is a re-

Correspondence to: D.J. Law lated, but distinct, member of the Tbxl subfamily, which we have designated TBX10.

By FISH analysis, human TBX10 maps to Chr 11q13 (Fig. 1). To refine the map location, human TBX10 was isolated in a $\mathrm{CEPH} / \mathrm{Genethon} \mathrm{YAC} \mathrm{contig} \mathrm{linked} \mathrm{to} \mathrm{anonymous} \mathrm{markers} \mathrm{span-}$ ning 11q13.1-q13.2 (Fig. 2A). YAC clones 894A10 and 809C9 were isolated using an STS based on TBX10 exon sequence (TBX10Exon-F:5' -TTAGACAGCTCGGCCTGG-3' and TBX10Exon-R: 5'-CATTGTCATCCAGCAGGTTG-3'). The YAC contig in Fig. 2A shows that human TBX10 is within $100 \mathrm{~kb}$ of anonymous marker AFMa152yh1 at 11q13.2. This places TBX10 in close proximity to the locus for Bardet-Biedl syndrome 1 (BBS1), an autosomal recessive disorder characterized by retinitis pigmentosa, polydactyly, obesity, hypogenitalism, mental retardation, and renal malformations (Bruford et al. 1997; Leppert et al., 1994).

Screening of the GenBank database with human TBX10 sequence identified mouse T-cell cDNA clones 550940 (GenBank Accession No. AA098449) as a highly significant match. A probe derived from this clone was mapped on the BSS backcross panel to proximal Chr 19 and co-segregated with marker D19Birl (Fig. 2B; MGD-JNUM-43729). This location is within a region of known synteny to human Chr 11q13 (DeBry and Seldin 1996).

To further confirm that we were studying the mouse ortholog of the human TBX10 gene, we compared available gene sequence outside of the highly conserved T-box (Fig. 3). High homology in

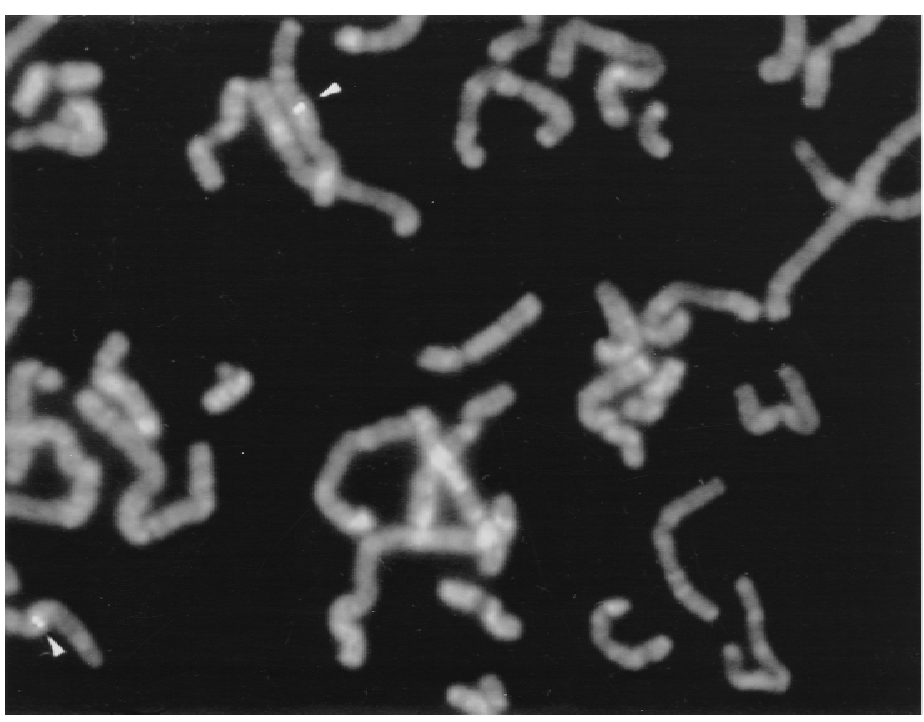

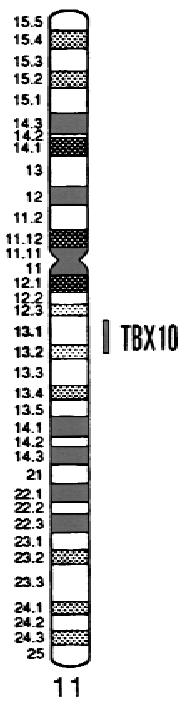

Fig. 1. FISH localization of human TBX10 to Chr 11q13. Human TBX10 $\lambda$ genomic clone LI014-1 was isolated by screening a lymph node library (ATCC LIO14) at low stringency with a mouse Tbx 1 cDNA probe (nt258-nt439 of GenBank entry MMU57327). Fifty $\mu \mathrm{g}$ of LIO14-1 was labeled with biotin by nick translation and hybridized to metaphase spreads of a 46XY male using a standard hybridization procedure (Trask et al. 1991). After being counterstained with DAPI, the chromosomes and hybridized probe were visualized through a dual-band pass filter (Chromatechnology). 
A)

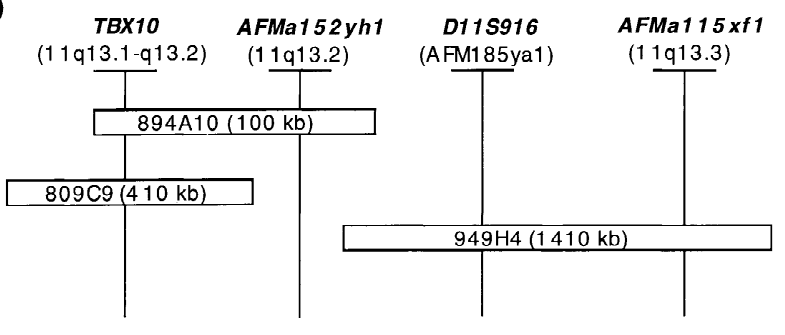

B)

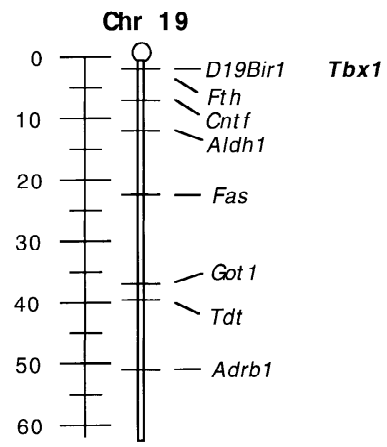

Fig. 2. Localization of TBX10. (A) Human CEPH/Genethon YAC contig encompassing TBX10 and linked to anonymous markers at Chr 11q13.1-11q13.2. Linkage to Genethon markers reported in the QUICKMAP database (www.cephb.fr/quickmap.html) was confirmed. STS content indicated by vertical lines; clones are not drawn to scale, since exact extent of Chr 11 content is not known. (B) Mouse Tbx10 cosegregates with D19Bir1 at map position 2 cM, using The Jackson Laboratory BSS backcross panel 2 (Rowe et al. 1994). The scorings are available at (www.jax.org/resources/ documents/cmdata/).

\begin{abstract}
HSTBX10: YQNHRITQLKIASNPFAKGFRESDLDSWPVAPR . . . PLLSVPARSRSSL . SPCVLKGATDREXDFQEGASAAQRTPTGPLWQEVA. LKLGLGGL MmTbx 10: YQNHRITQLKIASNPFAKGFREADPDSWPVTPR . . . PLLSI PARSNSSL . SPCLLKGSADREKDTSKASASSSRTPTQPHNQEDPTLAAGLGLL HSTBX1 : YQNHRITQLKIASNPFAKGFRDCDPEDWPRNHRPGALPLMSAFARSRNPVASPTQPSGT ... EKD MmTbX1 : YQNHRITQLKIASNPFAKGFRDCDPEDWPRNHRPGALPLVSAFARSRNPVASPTQPNGS...EKD
\end{abstract}

Fig. 3. Sequence comparisons among TBX10/Tbx10 and TBX1/Tbx1 coding regions within and $\mathrm{N}$-terminal to the T-box. Conserved residues, in bold type, among the subfamily members were determined from cDNA and genomic sequences (mouse Tbx10, Tbx1 and human TBX1) or genomic sequence alone (human TBX10; text and Chieffo et al. 1997). Mouse

Fig. 4. Northern blot analysis of RNA from mouse embryos aged $10.5 \mathrm{~d}$ to $17.5 \mathrm{~d}$. Total RNA isolated from $\mathrm{B} 6 \mathrm{D} 2 \mathrm{~F}_{1}$ embryos was prepared with Trizol Reagent (Life Technologies) or Fast Track

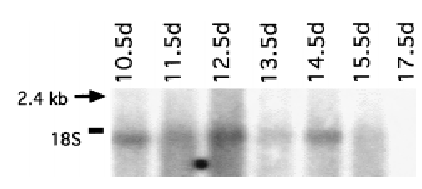
RNA Isolation Kit (Invitrogen). Hybridization was done by standard protocols. The blot was exposed for 5 days. Each lane contains $5 \mu \mathrm{g}$ total RNA.

such regions has been the most definitive criterion for establishing orthology among other T-box family members (Agulnik et al. 1995). The 69 putative amino acid residues at the C-terminal flank of the T-box are $61 \%$ identical, with nucleotide identity of $83 \%$, characteristic of orthology between the two genes. In addition, we analyzed the mouse genomic sequence across this region and found identical intron/exon structure in the two. Together with the syntenic map location of these genes, these data confirm that we have here identified the mouse and human orthologs of a new T-box family member.

Just as sequence similarity in regions outside the T-box is a measure of orthology, similarity and divergence within the conserved T-box provide a means to organize the T-box genes into subfamilies (Agulnik et al. 1995). Thus, comparison of the conserved T-box sequences of TBX10 with other T-box genes shows that it is a second member of the TBX1 subfamily.

It is notable that the TBX10/Tbx10 genes have regions of high sequence identity to TBX1/Tbxl within the $40-50$ residues immediately outside (C-terminal to) their T-box regions (Fig. 3). This characteristic is also present in this region of TBX2 (Tbx2 and 3) and TBX4 (Tbx4 and 5) subfamily members (not shown). The close sequence relatedness of the latter genes is thought to correlate with their complementary function in either the fore $(T b \times 5)$ or hind (Tbx4) limbs (Gibson-Brown et al. 1996; Agulnik et al. 1996).
Tbx10 genomic sequence was obtained from a BAC clone (Genome Systems), and exons predicted using GRAIL and comparative analyses. Intron positions are shown with arrows; the boxed region marks the highly conserved T-box. The human TBX10 exon nucleotide sequences reported here are contained in GenBank entries AF033574 through AF033579.

Ongoing studies of the two TBX10 subfamily members may reveal another instance of parallel functionality in such highly related T-box gene pairs. In particular, while that TBX1/Tbxl is expressed in adult testis in mouse and man (Bollag et al. 1994; Chieffo et al. 1997), we have found that TBX10/Tbx10 is expressed in female adult gonads (this report). This raises the possibility of alternative sex-specific functions and/or expression of this gene pair in these mutually exclusive tissues.

Preliminary analysis by RT-PCR suggests that TBX10 is expressed in human brain, ovary, uterus, pituitary, fetal kidney, and HeLa cells (data not shown). In the mouse, Northern analysis of mRNA from embryos of $8.5 \mathrm{~d}$ to $15.5 \mathrm{~d}$ gestation (Fig. 4), adult brain, liver, and kidney showed a single transcript of $1.9 \mathrm{~kb}$; it is absent in testis by both Northern analysis and RT-PCR, and present in adult ovary, uterus, and kidney by RT-PCR (data not shown). Preliminary in situ hybridization results suggest that its expression overlaps those found for Tbxl (Chapman et al. 1996) at $12.5 \mathrm{~d}$ gestation, in particular in the lung mesenchyme and tissues of the developing ear. The TBX10 expression pattern, together with its chromosomal location noted above, further enhances its candidacy for BBS1.

Acknowledgments. This work was supported by a grant from the National Institute of Child Health and Human Development (HD20275) to L.M. Silver and an NIH Human Genome Center Grant HG00209 (D.J.Law). We are grateful to Thomas Glover and Diane Miller in the Department of Human Genetics at the University of Michigan for the human FISH analysis and to Bindu Prabhakaran in the Department of Molecular Biology at Princeton University for invaluable assistance with in situ hybridization.

\section{References}

Agulnik SI, Bollag RJ, Silver LM (1995) Conservation of the T-box gene from Mus musculus to Caenorhabditis elegans. Genomics 25, 214-219

Agulnik SI, Garvey N, Hancock S, Ruvinsky I, Chapman DL, Agulnik I, Bollag R, Papaioannou V, Silver LM (1996) Evolution of mouse T-box 
genes by tandem duplication and cluster dispersion. Genetics 144, 249254

Bamshad M, Lin RC, Law DJ, Watkins WS, Krakowiak PA, Moore ME, Franceschini P, Lala R, Holmes LB, Gebuhr TC, Bruneau BG, Seidman JG, Seidman CE, Jorde LB (1997) Mutations in human TBX3 alter limb, apocrine and genital development in ulnar-mammary syndrome. Nat Genet 16, 311-315

Basson CT, Bachinsky DR, Lin RC, Levi T, Eikins JA, Soults J, Grayzel D, Kroumpouzou E, Traill TA, Leblanc-Straceski J, Renault B, Kucherlapati R, Seidman JG, Seidman CE (1997) Mutations in human cause limb and cardiac malformation in Holt-Oram syndrome. Nat Genet 15, 30-35

Bollag RJ, Seigfried Z, Cebra-Thomas JA, Garvey N, Davison EM, Silver LM (1994) An ancient family of embryonically expressed mouse genes sharing a conserved protein motif with the $T$ locus. Nat Genet 7, 383389

Bruford EA, Riise R, Teague PW, Porter K, Thomson KL, Moore AT, Jay M, Warburg M, Schinzel A, Tommerup N, Tornqvist K, Rosenberg T, Patton M, Mansfield DC, Wright AF (1997) Linkage mapping in 29 Bardet-Biedl syndrome families confirms loci in chromosomal regions 11q13, 15q22.3-q23, and 16q21. Genomics 41, 93-99

Chapman DL, Garvey N, Hancock S, Alexiou M, Agulnik SI, GibsonBrown JJ, Cebra-Thomas J, Bollag RJ, Silver LM, Papaioannou VE (1996) Expression of the T-box family genes, Tbx1-Tbx5, during early mouse development. Dev Dyn 206, 379-390

Chieffo C, Garvey N, Gong W, Roe B, Zhang G, Silver L, Emanuel BS,
Budarf ML (1997) Isolation and characterization of a gene from the DiGeorge chromosomal region homologous to the mouse Tbx1 gene. Genomics 43, 267-277

DeBry RW, Seldin MF (1996) Human/mouse homology relationships. Genomics 33, 337-351

Gibson-Brown JJ, Agulnik SI, Chapman DL, Alexiou M, Garvey N, Silver LM, Papaioannou VE (1996) Evidence of a role for T-box genes in the evolution of limb morphogenesis and the specification of forelimb/ hindlimb identity. Mech Dev 56, 93-101

Leppert M, Baird L, Anderson KL, Otterud B, Lupski JR, Lewis RA (1994) Bardet-Biedl syndrome is linked to DNA markers on chromosome 11q and is genetically heterogeneous. Nat Genet 7, 108-112

Li QY, Newbury-Ecob RA, Terrett JA, Wilson DI, Curtis ARJ, Yi CH, Gebuhr TC, Bullen PJ, Robson SC, Strachan T, Bonnet D, Young ID, Raeburn JA, Buckler AJ, Law DJ, Brook JD (1997) Holt-Oram syndrome is caused by mutations in hTBX5, a member of the Brachyury (T) family. Nat Genet 15, 21-29

Rowe LB, Nadeau JH, Turner R, Frankel WN, Letts VZ, Eppig JT, Ko MSH, Thurston SJ, Birkenmeier EH (1994) Maps from two interspecific backcross DNA panels available as a community genetic mapping resource. Mamm Genome 5, 253-274

Smith J (1997) Brachyury and the T-box genes. Curr Opin Genet Dev 7, 474-480

Trask BJ, Massa H, Kenwrick S, Gitschier J (1991) Mapping of human chromosome Xq28 by 2-color fluorescence in situ hybridization of DNA sequences to interphase cell nuclei. Am J Hum Genet 48, 1-15 